\title{
Tourism And The Environment: The Main Line Of Action For The European Union
}

Antonio Villanueva-Cuevas, University of Castilla-La Mancha, Spain ${ }^{1}$

\begin{abstract}
Tourism is one of the economic activities that most greatly affects the European Union, as this is the number one tourist destination in the world. Nevertheless, the current international economic crisis, together with the appearance of new tourist destinations in developing countries, has led to a need for new policies in matters of tourism, which are based in quality of service and in the sustainability of tourism. While this is not an entirely new idea, the drawing up of the European Agenda 21 for Tourism has been a key step forward in realizing this achievement.
\end{abstract}

Keywords: tourism; environment; sustainability; European Union.

\section{INTRODUCTION}

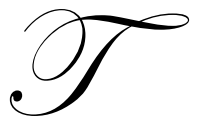

ourism has become the object of treatment by the European Union (henceforth EU) in relatively recent times. It would not be until the early 1980s when the EU, then known as the European Community, would express an interest in the tourism sector. This fact is even more curious when we stop to think that this is not only the number one tourist destination in the world, but the world's number one source of tourists. In addition, if we consider that the EU was created as a union whose character is first and foremost economic, the fact that it took such a late interest is even more surprising. Possibly, this has to do with the fact that that was the decade when countries with impressive interest joined the EU, such as Spain and Greece. This can be added to other information, including the consideration that matters of tourism ought to be governed by state, regional or local authorities, since these entities are well acquainted with the problems and can therefore offer the best solutions. The diverse interest each Member State has in the tourism sector must also be considered, some as tourist sources, others as tourist recipients, and others from both perspectives. All of these factors can help us to understand the EU's late intervention in this sector.

And reserving the right to a more complete analysis of the EU's performance in this sector, the worthy subject of another article, one of its guidelines has always insisted on the link between tourism and the environment. The EU is fully conscious that mass tourism creates a kind of pressure that is sometimes excessive for the natural resources in places receiving tourists; for example, the Spanish coast. It is precisely these resources that attract the interest of tourists to these territories, meaning that tourist demands must adapt to the necessary protection of these resources. Above all, they must be maintained in such a way that they can continue to generate tourist flow.

Together with the above line of argument, in the past few years it has been confirmed that while the European tourism sector has continued to expand, it has not kept up with the growth of tourist destinations in emerging foreign countries. This has created a need for the EU to develop a new policy that outlines the link between tourism and quality of service. To this end, the development of sustainable tourism has become an essential term. Below, we will have a look at those measures adopted by the EU in order to reach this goal.

\footnotetext{
${ }^{1}$ This paper is included in the investigation project "Nuevas perspectivas del Derecho Ambiental", financed by Ministerio de Ciencia y Tecnología, Gobierno de España, Ref. DER2010- 21571.
} 


\section{First Signs Of Sustainable Tourism In The European Union}

When the EU first began to address the issue of tourism, it was already clearly concerned about the sector's environmental aspects. For example, in the European Parliament Resolution of January $22^{\text {nd }}, 1988$ (Resolution on the expedition, promotion and consolidation of tourism in the European Union" DOCE 49/1988, from 22-02-1988, series C) a mention was made that the European Union should show a greater determination in certain aspects of tourist activities considered essential. Emphasis was placed on the protection of natural, social and cultural areas against the dangers of mass tourism.

Nevertheless, the binding tie between tourism and the environment would not come until the middle of the 1990s, specifically in the Commission's Green Book on the EU's role in matters of tourism (DOCE 97/1995, from 4-04-1995, series COM). The document emphasized that one of the objectives that ought to be reached by the EU in matters of tourism was the meaningful contribution to the achievement of a sustainable development.

But it would be the unsuccessful program "PHILOXENIA" that outlined the actions to be developed by the EU from 1997 to 2000, which would state that one of the pre-eminent lines of action that should be undertaken by the EU should be to increase the quality of European tourism through the promotion of sustainable tourism. To this end, the document outlined a series of measures, which were still quite abstract and even weak. Among these were the application of environmentally respectful management systems in tourist destinations and the biannual organization of a "European Tourism and Environment Prize" (letter C, point 1, of the program's attachment).

Still, the absence of a true common European policy in matters of tourism, which at that time had already been requested on several occasions, but which was still far from being articulated because it lacked the necessary legal backing in EU Constituent Treaties, can be considered the main obstacle for the achievement of these and other goals in relation to the EU tourism sector. The prevailing notion, then and now, that tourism is a sector whose primary activity must happen at a state, regional or local level, and that EU actions must be only supplementary, has caused actions taken on a European level to be inefficient, more closely resembling mere intentions than clear decisions.

\section{Development Of Sustainable Tourism In The EU: Involvement Of All Affected Sectors}

It would be at the beginning of the $21^{\text {st }}$ century when the need for sustainable tourism within the EU would start to develop and action in matters of tourism would become a priority.

To this end, the EU would follow international guidelines which were being defined at that time: among others, in 1996, the World Travel \&Tourism Council (WTTC), the World Tourism Organization (OMT) and the Earth Council drew up the Agenda 21 for the industry of travel and tourism; in 1999, the OMT general assembly adopted the Global Code of Ethics for Tourism, which pledged a commitment to the principles of sustainability; and the document entitled International Guidelines on Sustainable Tourism, written by the United National Environmental Program (UNEP) and the Convention on Biological Diversity. The EU itself would even write the so-called COMMISSION WHITE BOOK "European transport policy for 2010: time to decide", which it would use in efforts to achieve more efficient and more sustainable means of transportation for tourists.

And so, the Commission would write up a Communication entitled "Basic guidelines for the sustainability of European tourism" (Brussels, November 21 ${ }^{\text {st }}$, 2003, COM 2003), which would outline, on one hand, a set of directive measures that should be carried out by the EU, but which, on the other hand, and this is the truly important part of the document, attempts to involve all parties with an interest in the tourism sector, starting with the EU itself, including international organizations, national and local governments, private parties and finally citizens and tourists. Let's have a look at the measures anticipated by the Commission:

- $\quad$ Starting with the Commission itself, it must incorporate sustainability in all EU policy that affects tourism and attempt to make policies that are specifically related to tourism more efficient in terms of sustainability. But it must also favor the synergy and cooperation between parties in the sector and must promote sustainable models of tourist consumption and production. 
- International organizations and state governments must, in the opinion of the Commission, increase their efforts to achieve a higher level of coordination, but above all, they must pay particular attention to sustainability and encourage models of sustainable consumption. For example, they should adopt measures that are not temporary in nature, thus avoiding overcrowding at certain times of the year.

- $\quad$ But perhaps one of the most relevant levels is that of local authorities, as they are the ones who have a direct knowledge of the impact tourism has in their territory and must adopt necessary measures to keep it to a minimum, taking advantage of EU resources when necessary. In addition, they must incorporate sustainability in their policies, for example, in matters of transport and urban planning.

- Tourism firms must also engage in sustainable business practices, including matters of seasonal considerations and transport. Simply put, they must offer products that incorporate sustainable qualities. For example, they can have tourists pay the total costs of the product, including environmental costs, but they must also consider the local population in their decisions, especially when these affect indigenous culture or territory.

- $\quad$ Finally, citizens/tourists must act in a responsible manner, which is to say, in a sustainable manner. They should, for example, make purchases which are sustainable, and to this end, these products must be clearly and truthfully marked.

- Non-Governmental Organizations must contribute to the process, providing innovative solutions in a constructive manner, and as such, must outline effective channels of participation.

Of the specific measures articulated by the Commission in that document in favor of sustainable tourism, we must highlight the creation of a group dedicated to the sustainability of European tourism. Created in 2004, the group is made up of experts in the representation of business associations, representatives of tourist destinations and labor and civil society organizations. It also includes representatives from the Administrations of Member States and from international organizations, and is dedicated to environmental matters.

But above all, we must stop and take a look at a very specific measure: the creation of the European Agenda 21 for tourism.

\section{European Agenda 21 For Tourism}

The road to the creation of the European Agenda 21 for Tourism was a long one, and has therefore been highlighted by the Commission. But the most important moment in the creation of this Agenda came in the Commission's Communication entitled "Agenda for a sustainable and competitive European tourism" (Brussels, 19.10.2007, COM 2007, 621 final), in which this proposal is defined and developed.

This Communication insists on the need for the development of a European tourism industry which is more competitive and which is also more respectful of the environment. That is to say, sustainable, an element whose quality sets it apart from other emerging destinations. In order to do this, the creation of sufficient public policies was fundamental, policies based in the sustainable management of destinations and the integration of sustainability in the actions of tourist businesses and of tourists themselves.

In order to achieve these objectives, the Commission outlined several principles and invited all participating parties in the sector to respect them. These principles are (Communication,..., Agenda for a Sustainable..., op. cit., pg. 6): “...

- Take a holistic and integrated approach.

- $\quad$ Plan for the long term.

- $\quad$ Achieve an appropriate pace and rhythm of development.

- Involve all stakeholders. 
- $\quad$ Use the best available knowledge.

- $\quad$ Minimize and manage risk (the precautionary principle).

- $\quad$ Reflect impacts in costs (user and polluter pays).

- $\quad$ Set and respect limits, where appropriate.

- $\quad$ Undertake continuous monitoring."

In order to see the results of these action criteria, the Commission encouraged all involved parties in the tourism sector to intensify their level of participation. In addition, it acknowledged its responsibility for action in these matters, continuing in the role of carrying out initiatives on the EU level with the following objectives (Comunication,..., Agenda for a Sustainable,..., beginning on pg. 8.): “...

- $\quad$ Mobilizing actors in the tourism sector to produce and share knowledge

- $\quad$ Promoting destinations of excellence

- $\quad$ Mobilizing the EU financial instruments

- Mainstreaming sustainability and competitiveness in Commission policies"

\section{Consolidation Of Sustainable Tourism As One Of The Basic Central Ideas Of The New Common Policy In Matters Of Tourism}

But beyond these documents, significant in and of themselves because sustainability became an objective here for the EU in matters of tourism, the most important point in our opinion came about as the result of the adoption of a new EU framework in matters of tourism following the receipt of this material in the Treaty of Lisbon, and that it featured sustainability as one of its basic tenets.

Until that time, attempts at sustainability were made only through sector-specific policies which influenced tourism, like transport, for example. We can point to isolated actions that are quite relevant for the protection of specific territorial areas in the EU that are vulnerable to excessive tourism levels, like the signing and later ratification by Decision of the Council representing the Community of the Protocol on Tourism from the Alpine Convention (Brussels, from 29-06-2005, Or. in, 14218/05, and from 22-06-2006, Or. in, 10193/1/06 Rev 1, respectively).

But in our opinion, the problem of sustainability in European tourism could be found in the limited powers the EU had for imposing on Member States a true EU policy in the tourism sector. From the beginning of EU intervention in these matters, it has been held that the key actions in tourism should be locally based in their majority, because the Member States, regions and Local Entities are most directly familiar with the problems facing tourism, and these bodies are able to present solutions more quickly and more in accordance with the specificities of each territory, making it necessary for EU actions in the sector to remain absolutely respectful to the principle of subsidiarity. European measures could only provide added value to the actions of each State.

Many were the voices demanding that a specific chapter dedicated to tourism be included in the Constituent Treaties, especially at the beginning of the 1990s. But over and over again the modification was rejected. The various interests of each Member State, together with the traditional idea that the overwhelming power in the tourism sector belonged to each State, played a large role in the pattern of rejection.

And without looking too closely at this process, which is the subject of a future study, what is certain is that actions on a state level had been fairly accurate, a fact which is supported by the numbers of tourists received by Europe. Nevertheless, the situation also had its disadvantages: the limited possibility for EU action, lower budgetary limits for actions in matters of tourism, a shortage of human resources in the common organization of the sector, a certain lack of coordination between actions carried out by the Member States, and more.

Still, in the early $21^{\text {st }}$ century, a variety of factors would begin to appear that would contribute in a decisive way to a change in EU strategy in matters of tourism: the confirmation that European tourism was growing, but below the world average, especially when compared to emerging destinations. Also, the need to respond to the new 
challenges facing tourism (new internal destinations, outside competition, the lack of qualified labor, quality of services, the introduction of the Euro, the deregulation of public transport and more). All of this would make it necessary to ensure a higher level of coordination, and a new strategic framework began to be created for what would be a genuine common policy in matters of tourism.

This opinion trend would find definitive backing following its incorporation in the Treaty of Lisbon (art. 195 from the Consolidated Text of the Treaty on the Functioning of the European Union, DOCE, 30.03.2010, C 83/47) regarding specific material powers directed at the support, completion and coordination of actions by Member States, thus moving toward clearer, more coherent action, making sure that this does not result in the coordination of legal and regulatory provisions by Member States.

Obviously, these powers do not compare to those recognized by the EU in other matters that have already been referred to, and it will depend on the development of these powers that the Members States hope for in the future, to determine their true relevance. But what is certain is that this new framework of action has seen results in a short amount of time: focusing exclusively on the field of sustainable tourism, the informal ministerial meeting organized by the Spanish Presidency of the Council held on April 15 ${ }^{\text {th }}$, 2010 was a decisive step with the goal of obtaining the commitment of the EU and all Member States, to work toward a tourism sector that is more competitive, sustainable, modern and socially responsible.

As the expression of this new policy, in June of 2010, the Commission presented a Communication based in these new powers in order to describe a wide range of measures that aim to foment European tourism and its evolution and adaptation to the challenging economic times we are currently facing (European Commission Communication, "Europe, the world's number one tourist destination: a new political framework for tourism in Europe" Brussels, 30.6.2010, COM 2010352 final). And the new framework the Commission attempts to establish in favor of tourism is based in four basic central ideas, one of which is to promote the development of sustainable, responsible and high-quality tourism.

In order to reach this goal, the Commission outlined a series of specific measures: “...

11) Develop, on the basis of NECSTouR or EDEN, a system of indicators for the sustainable management of destinations. Based on this system, the Commission will develop a label for promoting tourist destinations.

12) Organize awareness-raising campaigns for European tourists concerning the choice of destinations and means of transport, relationships with the local population in the destinations visited, and combating the exploitation of woman and children.

13) Develop a European 'Qualité Tourisme' brand, based on existing national experience, to increase consumer security and confidence in tourism products and reward rigorous efforts by tourism professionals whose aim is quality of tourism service for customer satisfaction.

14) Facilitate identification by the European tourism industry of risks linked to climate change in order to avoid loss-making investments, and explore opportunities for developing and supplying alternative tourism services.

15) Propose a charter for sustainable and responsible tourism and establish a European prize for tourism businesses and destinations respecting the values set out in the charter.

16) Propose a strategy for sustainable coastal and marine tourism.

17) Establish or strengthen cooperation between the European Union and the main emerging countries (China, Russia, India, Brazil) and Mediterranean countries to promote sustainable and responsible tourism development models and the exchange of best practice." 
And this is the situation, still in its infancy, in which we currently find ourselves—with a need to evaluate the Comission in 2011 as to how it has progressed in this matter.

\section{CONCLUSION: SUSTAINABILITY AS AN IDENTITY FOR EUROPEAN TOURISM}

Having finished this study, one might conclude that the EU treats sustainability differently than it does other specific actions in the tourism sector. We are not talking about a line of action that is simply added on to other actions in matters of tourism, like the improvement of statistics or of awareness in tourist sectors. Rather, what we are referring to is that the EU is going one step further, saying that it will only consider a kind of tourism that is sustainable. It identifies competitiveness, quality and development of the European tourism business model with sustainability to such a point that it considers that the future of this sector will be tied to the quality of the tourist experience, in which the sustainability factor must be integrated. In our opinion, it is not possible to speak of European tourism without speaking of sustainable European tourism.

Nevertheless, this must not prevent us from keeping in mind how tourism has been treated by the EU. Even if the EU now has new powers which can at least coordinate, complete and support the actions of the States for the achievement of a sustainable tourism, what is certain is that these States must develop, and whether they reach their goal will depend on their evolution.

Keeping our focus on Spain, it is currently the Autonomous Communities which possess a competitive exclusivity in this matter, and all of these bodies have passed laws of tourism planning, in which environmental protection is anticipated, but with an intensity which is fairly relative, and of course, in some way from the integrated perspective articulated by the EU. The differences between the Autonomous Communities are substantial as far as the interests each possesses, and protection is reflected more in the need to respect existing environmental regulations in the development of activities carried out by tourism companies (through obtaining previous authorization) than in propping up tourism through sustainability, holding the companies themselves responsible but also tourists, Public Administrations and all other interested parties in the sector (FERNÁNDEZ RODRÍGUEZ, 2005, beginning on pg. 22).

It will be the job of European institutions to teach the Member States and regions that the future of European tourism must be based in sustainability as a path toward quality and competitiveness, but in such a way that this characteristic is the "mark of quality" for European tourism, not merely another characteristic. For this to take place, their new functions of coordination and support for the Member States, having been well taught, could prove to be essential.

\section{AUTHOR INFORMATION}

Antonio Villanueva Cuevas: Degree in Law by University of Castilla-La Mancha. Assistant Profesor in Public Law at Public Law Department. Faculty of Social Sciences of Cuenca. University of Castilla-La Mancha (Spain). Research Interest: environment, tourism, urbanism, European Union Law. E-mail: Antonio.Villanueva@uclm.es.

\section{REFERENCES}

1. Fernández Rodríguez, C. (2005). Derecho Administrativo del Turismo. Marcial Pons, Ediciones Jurídicas y Sociales, Madrid/Barcelona, $3^{\text {a }}$ edición.

2. Comisión Europea, (2000). Por un turismo costero de calidad: Gestión integrada de la calidad de los destinos turísticos costeros : resumen. Dirección General de Empresa, Unidad Turismo, Luxemburgo: Oficina de Publicaciones Oficiales de las Comunidades Europeas, 2000.

3. Comisión Europea, (2003). El patrimonio natural y cultural como factor de desarrollo del turismo sostenible en los destinos turísticos no tradicionales. Dirección General de Empresa, Luxemburgo: Oficina de Publicaciones Oficiales de las Comunidades Europeas, 2003.

4. Díez de Velasco Vallejo, M., (1999). "Reflexiones sobre el turismo y el desarrollo del medio ambiente en la Unión Europea”. En: Congreso Universidad y Empresa $2^{\circ}$. Benicásim. Turismo : comercialización de productos, gestión de organizaciones, aeropuertos y protección de la naturaleza, pgs. 485-496.

5. European Commission, (2001). Sustainable tourism and Natura 2000: Guidelines, initiatives and good 
practices in Europe; Final Publication based on the Lisbon seminar, December 1999 28/10/0./ Environment DG, Luxembourg : Office for Official Publications of the European Communities.

6. European Union; Committee of the Regions (2006). Sustainable tourism as a factor of cohesion among European Regions. Luxemburgo: Office for Official Publications of the European Communities.

7. La Constitución Europea, implicaciones para el sector turístico. Madrid : UIMP: Paradores, 2007.

8. Molés Molés, V.J., (2003).El papel de la Comisión Europea en turismo: propuesta de misión, estrategias de futuro y estructura organizativa / tesis doctoral. Director, Enrique de Miguel Fernández, Valencia: Universidad Politécnica de Valencia.

9. Valdés Peláez, L, et a, (2001). Turismo y medio ambiente. José D. Buendía Azorín, José Colino Sueiras (editores). Madrid : Civitas.

\section{DOCUMENTATION (in chronological order)}

1. Resolución Del Parlarmento, "Resolución relativa a la facilitación, promoción y consolidación del turismo en la Comunidad Europea". DOCE 49/1988, de 22-02-1988, serie C.

2. Libro Verde De La Comisión sobre "El papel de la Unión Europea en materia de turismo". Doce 97/1995, De 4-04-1995, Serie Com.

3. Informe De La Comision Al Consejo, Al Parlamento Europeo, Al Comite Economico Y Social Y Al Comite De Las Regiones sobre las medidas comunitarias que han afectado al turismo en 1994 Decisión Del Consejo 92/421/Cee) Com/96/0029 Final.

4. Informe sobre la evaluación del Plan de acciones comunitarias en favor del turismo 1993-95 Decisión Del Consejo 92/421/Cee) Com/96/0166 Final.

5. Propuesta De Decisión Del Consejo sobre un primer programa plurianual en favor del turismo europeo «Philoxenia» (1997-2000) COM/96/0168 final.

6. Propuesta Modificada De Decisión Del Consejo sobre un primer programa plurianual en favor del turismo europeo «PHILOXENIA $»(1997-2000)$ COM/96/0635 final - CNS 96/0127.

7. Informe De La Comisión Al Consejo, Al Parlamento Europeo, Al Comité Económico Y Social Y Al Comité De Las Regiones sobre las medidas comunitarias que afectan al turismo (1995/96) COM/97/0332 final.

8. Comunicación De La Comisión Al Consejo Y Al Parlamento Europeo, Una estrategia de apoyo al desarrollo de un turismo sostenible en los PVD para la Comunidad Europea, COM/98/0563 final.

9. Comunicación De La Comisión Al Consejo, Al Parlamento Europeo, Al Comité Económicos Y Social Y $\mathrm{Al}$ Comité De Las Regiones, Incrementar el potencial del turismo como generador de empleo Seguimiento de las conclusiones y recomendaciones del Grupo de Alto Nivel sobre Turismo y Empleo, Diario Oficial ${ }^{\circ}$ C 178 de 23/06/1999.

10. Informe De La Comisión Al Parlamento Europeo, Al Consejo, Al Comité Económico Y Social Y Al Comité De Las Regiones, Medidas comunitarias con incidencia en el turismo (1997/99) COM/2001/0171 final.

11. Comunicación De La Comisión Al Consejo, Al Parlamento Europeo, Al Comité Económico Y Social Y Al Comité De Las Regiones, Un marco de cooperación para el futuro del turismo europeo, COM/2001/0665 final.

12. Comunicación De La Comisión Al Consejo, Al Parlamento Europeo, Al Comité Económico Y Social Y Al Comité De Las Regiones, Orientaciones básicas para la sostenibilidad del turismo europeo, Bruselas 21 de noviembre 2003, COM (2003), 716 final.

13. Proyecto De Conclusiones Del Consejo Sobre La Sostenibilidad Del Turismo Europoeo, Bruselas, 15 de abril de 2005, (OR. en) 8096/05.

14. Comunicación De La Comisión, Una nueva política turística en la UE: hacia una mayor colaboración en el turismo europeo, Bruselas, 17.3.2006 COM(2006) 134 final

15. Comunicación De La Comisión, Agenda para un turismo europeo sostenible y competitivo, Bruselas, 19.10.2007, COM(2007) 621 final.

16. Conclusiones Del Consejo Sobre la Agenda para un turismo europeo sostenible y competitivo, Bruselas, 29.10.2007 (10.12) (OR. En). 
17. Comunicación De La Comisión Al Parlamento Europeo, Al Consejo, Al Comité Económico Y Social Europeo Y Al Comité De Las Regiones, Europa, primer destino turístico del mundo: un nuevo marco político para el turismo europeo, Bruselas, 30.6.2010 COM(2010) 352 final. 